\title{
Mina tratatzeko estrategia farmakologiko berriak: kannabinoideak aztergai
}

\author{
New pharmacological strategies for pain treatment: cannabinoids under \\ examination
}

\author{
Erik Aostri, Joseba Pineda eta Aitziber Mendiguren \\ Farmakologia Saila, Euskal Herriko Unibertsitatea, UPV/EHU \\ aitziber.mendiguren@ehu.eus
}

\section{Laburpena}

Ehunetako benetako kaltearekin edo kalte potentzialarekin erlazionatutako esperientzia sentsorial eta emozional desatsegina da mina, eta sailka daiteke jatorriaren arabera (nozizeptiboa, neuropatikoa), larritasunaren arabera (arina, larria) zein iraupenaren arabera ere (akutua, kronikoa). Oro har, gaur egun mina tratatzeko merkaturatuta dauden farmakoak eraginkorrak dira, baina epe luzera erabiltzean arazoak ager daitezke. Adibidez, opiazeoak analgesiko indartsuak diren arren, kronikoki ematean haien eraginkortasuna txikitu daiteke eta eragin desiragaitzak agertu. Estatistikak dio populazioaren \% 15ek min kronikoa jasaten duela. Min kronikoak norbanakoa ezindu dezake eta hura arintzea zaila gerta daiteke. Horregatik, mina tratatzeko estrategia eta itu berrien ikerketak beharrezkoak dira. Ikergai dagoen itu bat sistema kannabinoidea da. Barneko kannabinoideak giza gorputzak ekoizten dituen molekulak dira, zeinek kannabinoide-hartzaileei (CB) lotuz funtzio fisiologiko ugari erregulatzen dituzten, mina adibidez. Cannabis generoko landareetan aurki daitezkeen landare-kannabinoideek barneko sistema horren aktibazioaz baliatuz analgesia eragin dezakete. Zoritxarrez, horietako kannabinoide batzuk psikoaktiboak dira, minaren tratamendurako mugatzailea den ezaugarria. Horregatik, azken urteotan kannabinoide ez-psikoaktiboen gaineko ikerkuntzek bultzada handia jaso dute eta minaren tratamendurako kannabinoide psikoaktibo eta ezpsikoaktiboen arteko nahasketak zenbait saio klinikotan probatu dira. Azkenik, eraginkortasun/segurtasun erlazioa hobetzeko asmoz, kannabinoide eta opiazeoen elkarketak ikertu izan dira, eragin analgesiko sinergikoa lortzeko eta dosi txikiagoak erabilita segurtasuna handitzeko. Beraz, kannabinoideen inguruko ikerkuntzak bide berriak zabaltzen ditu minaren tratamendurako estrategia farmakologiko hobeak bilatzeko.

Gako hitzak: mina, kannabinoidea, analgesia, CB hartzailea, opiazeoa, kannabidiola

\section{Abstract}

Pain is an unpleasant sensory or emotional experience that is associated with ongoing or potential tissue damage and it can be classified by its origin (nociceptive, neuropathic), severity (mild, severe) or duration (acute, chronic). In general, commercially available drugs for pain relief are effective, but their long-term use can lead to several problems. For example, although opioids are very strong analgesics their efficacy can decrease when chronically used and safety problems can appear. According to statistics, $15 \%$ of the population suffers from chronic pain. Chronic pain is a disabling state, which can be difficult to treat. Thus, the finding of new analgesic drugs and research into new targets and strategies is essential. One of the systems that is currently under investigation is the endocannabinoid system. Endogenous cannabinoids are synthesized in the human body and they regulate several physiological processes (e.g. pain) through activation of cannabinoid receptors. 
Cannabinoids are present in the Cannabis plant and induce analgesia by regulating the endogenous cannabinoid system. Unfortunately, some of the cannabinoids are psychoactive, which is a feature that limits their therapeutic use. In recent years, research into non-psychoactive cannabinoids has increased and they have been tested in several clinical trials together with psychoactive cannabinoids. Finally, in an attempt to improve the efficacy/safety ratio, a combination of opioids and cannabinoids are being studied with the objective of achieving synergistic analgesic effects and decreasing side effects. Overall, research into cannabinoids has opened up new ways for finding better pharmacological strategies for pain treatment.

Keywords: pain, cannabinoid, analgesia, CB receptor, opioid, cannabidiol

Bidalia: 2017ko uztailaren 7an.

http://doi.org/10.26876/osagaiz.2.2017.91

Onartua: 2017ko azaroaren 30ean.

\section{Sarrera}

Mina: kaltetutako edo kaltetu litezkeen ehunen berri ematen digun sentsazio desatsegina eta bizipen emozionala. Era horretan, mina norbanakoaren biziraupenerako ezinbestekoa da, kalte larriagoak saihestea ahalbidetzen duelako. Hala ere, mina denboran gehiegi luzatzen denean edo min beraren sorrera aberrantea denean, arazo larriak dakartza. Populazioaren seirenak min kronikoa du eta mina jasaten dutenen herenak ez du min hori tratatzen. Tratatu gabeko min kronikoa eguneroko bizitzarekin bateraezina izan daiteke, horregatik eraginkortasun eta segurtasun handiko analgesikoen bilaketa etengabekoa da. Gaur egun, minaren tratamendurako dauden analgesikoak seguruak eta eraginkorrak dira, baldin eta tratamendua denboran gehiegi luzatzen ez bada. Denboran luzatzen den mina (min kronikoa) tratatzeko, aitzitik, segurtasun eta eraginkortasunaren aldetik arazo ugari ager daitezke. Hori dela-eta, mina tratatzeko farmako, itu eta akzio-mekanismo berriak topatzea premiazkoa da. Itu berrien artean barneko kannabinoide-sistema dago. Sistema hori sintetikoki zein kannabisaren landareak ekoitzitako kannabinoideekin erregula daiteke eta mekanismo desberdinen bidez analgesia eragin. Artikulu honetan, hain zuzen ere, mina tratatzeko erabilgarriak izan daitezkeen kannabinoideei buruz arituko gara.

\section{Min-motak eta gaur egungo tratamendua}

Egungo minaren kontzeptuak aspektu fisiologikoak zein emozionalak biltzen ditu. Horrela, minaren anizkoiztasuna bildu zuen lehenengo teoria 60ko hamarkadan argitaratu zen. Zehazki, 1965ean Melzackek eta Wallek minaren pertzepzioak dituen aspektu psikologikoei azalpen fisiologiko bat eman zieten. Eredu horretan, adar dortsalak periferiatik datozen estimuluen fluxua modulatu dezake, ate bat balitz moduan (1). Minaren pertzepzioa norbanakoaren araberakoa ere izango da. Gaur egun, Mina Ikertzeko Nazioarteko Elkarteak mina honela definitzen du: ehunetako benetako kaltearekin edo kalte potentzialarekin erlazionatutako esperientzia sentsorial eta emozional desatsegina (International Association for the Study of Pain, IASP). Definizio hori era praktiko eta kliniko batera eramanda, pazienteak jasaten duen esperientzia sentsorial desatsegina izango litzateke, erantzun afektibo, motor eta begetatiboarekin batera agertzen dena.

Minak alderdi subjektiboa duen arren, irizpide objektiboen arabera sailka daiteke. Modu horretan, iraupenaren arabera min akutua eta kronikoa (gutxienez, 3 hilabetetan zehar gertatzen dena) bereiz ditzakegu, eta kokapenaren arabera somatikoa eta erraietako mina. Hala ere, desberdintasun nagusia minaren jatorrian dago. Horren arabera, min nozizeptiboa gorputzetik barreiatuta dauden hartzaile nozizeptiboen kitzikapenarekin erlazionatzen da eta horrek dakarren nerbio-seinalearen transmisioarekin. Min neuropatikoa, ordea, estimulu zehatz baten absentzian sor daiteke nerbiosistemaren funtzionamendu desegokiak eraginda. Hala ere, kasu batzuetan min neuropatikoaren eta nozizeptiboaren arteko bereizketa ez da hain erraza, min neuropatikoa gorputzaren min-atalasea jaitsi duen estimulu nozizeptibo iraunkor baten ondorioz ere gerta daitekeelako. Azkenik, gaur egungo aditu eta nazioarteko batzorde gehienek onartzen dute minbiziarekin lotutako mina talde 
berezi batean sailkatu behar dela, ezaugarri klinikoak eta farmakoekiko sentikortasuna bestelakoak baitira.

Min nozizeptiboaren eredu klasikoan, estimulu batek periferian dauden nerbio-zuntzak kitzikatzen ditu. Nerbio-zuntz horien bukaeretan katioi-erreten ugari daude eta bertan axoietatik bidaiatuko duen seinale elektrikoa sortuko da. Oro har, nozizepzio-seinale fisiologikoaren garraioan A- $\delta$ eta Czuntzek hartzen dute parte. A- $\delta$ zuntzek estimulu termiko eta mekanikoak garraiatzen dituzte; Czuntzek, berriz, estimulu kimiko, termiko eta mekanikoak (2). Nozizepzio-seinaleak modulaziopean daude eta funtzio horren arduradunak, besteak beste, glizina, azido g-aminobutirikoa (GABA), serotonina, noradrenalina, dopamina eta opioide endogenoak dira (2). Alegia, burmuin-enborrak seinalea jaso ondoren beheranzko inhibizio-seinale nagusia aktibatzen da. Estimulua denboran luze mantenduko balitz, sentsibilizazioa nerbio-sistema zentralean (NSZ) gertatuko litzateke eta, ondorioz, nerbio-sistemak mina arintzeko duen gaitasuna txikituko luke. Horretaz aparte, hantura-prozesuetan hartzaile nozizeptiboen sentsibilizazioak minarekiko sentikortasuna handitu dezake (hiperalgesia), hanturarekin erlazionatutako molekulek eraginda (prostaglandinek kasu). Hori dela-eta, mina tratatzeko analgesikoak espero baino dosi altuagoetan eman beharko dira askotan, eta, horregatik, garrantzitsua izango da efektu desiragaitz txikiak dituzten farmakoak erabiltzea. Mina tratatzeko estrategiarik onena giza sistema endogenoaz baliatzea da, hau da, gure organismoan bai NSZan bai eta periferikoki kokatuta dauden hartzaile, garraiatzaile eta itu ezberdinak aprobetxatzea analgesia eragiteko ere.

Minaren tratamenduan lehenengo pausoa min mota (inflamatorioa, erraietakoa, neuropatikoa...) bereiztea da. Behin minaren sailkapena eginda, berau nozizeptiboa denean, Osasunaren Munduko Erakundeak gomendatzen duen protokoloan kontuan hartzen den irizpidea larritasuna da. Hau da, gaixoaren mina zenbat eta handiagoa izan, orduan eta farmako eraginkorragoak emango zaizkio. Farmako eraginkorrenen artean ezagunenak opiazeoak dira, hau da, barneko sistema opioidea aktibatzen dutenak. Morfina, esaterako, giza gorputzean dauden hartzaile opioideei lotzen zaie analgesia indartsua eta bizkorra sorraraziz. Farmako-talde hori, segurtasun-arazoak tarteko, ez da medikuaren lehenengo agindua izaten min arinaren tratamendurako. Horrela, min arina tratatzeko antiinflamatorio ez-esteroideoak (AIEE) erabili ohi dira, hanturaren arduradunak diren prostaglandinen sintesia inhibitzen dutenak (adibidez, ibuprofenoa). AlEEen eragin desiragaitz ohikoenak urdail eta hesteetako narritadurak izaten dira, baina, oro har, eraginkortasun mugatua duten farmako seguruagoak dira. Mina larriagoa denean, berriz, AIEEak opiazeoekin batera errezetatzen dira. Lehenengo opiazeo ahulekin hasiko litzateke eta mina arinduko ez balitz, gaixoari opiazeo indartsuagoak emango litzaizkioke. Zoritxarrez, opioide-hartzaileen aktibazio jarraituak (adibidez, min kronikoa tratatzeko) menpekotasuna eta arnas depresioa eragin ditzake. Gainera, opiazeoen tratamendu luzeetan tolerantziaren fenomenoa ager daiteke, hau da, opiazeoen dosi handiagoak behar izatea eragin analgesikoa mantendu ahal izateko.

Aurreko guztia kontuan hartuta, beharrezkoa dirudi AIEEak baino analgesiko indartsuagoak topatzea, baina era berean opiazeoak baino seguruagoak direnak edota opiazeoen segurtasuna hobetu dezaketen farmakoak, adibidez menpekotasuna eta tolerantzia txikituz. Zentzu horretan, azken urteotan opiazeoekiko tolerantzia aztertzen duten ikerlan ugari argitaratu dira. Horietariko batzuek bide berriak proposatzen dituzte tolerantzia txikitzeko, adibidez, oxido nitrikoaren sistemaren modulazioa. Zehazki, morfinaren tratamenduak eragindako tolerantzia analgesikoa oxido nitrikoaren sintesia inhibituz murriztu daiteke (3). Gainera, oxido nitrikoaren bidea modulatuz posible da tolerantziaren oinarri molekularra den hartzaile opiazeoen desentsibilizazioa ere txikitzea $(4,5)$. Tolerantzia txikitzeko eta, beraz, eraginkortasuna emendatzeko beste era bat opioideak kannabinoideekin batera ematea izan liteke.

\section{Mina tratatzeko itu berriak: kannabinoide-sistemaren modulazioa}

Gaur egungo terapia analgesikoaren mugak ikusita, bereziki min kronikorako, premiazkoa bilakatu da analgesiko indartsu eta seguru berriak topatzea. Bilaketa horren emaltzetako bat kannabinoideak dira. Kannabinoideak gorputz osoan zehar sakabanatuta dauden kannabinoide-hartzaileei (CB) lotzen zaizkien molekulak dira. 


\subsection{Barneko kannabinoide-sistema: giza gorputzaren berezko analgesikoak}

Giza gorputzean bi kannabinoide nagusi identifikatu dira: 2-arakidonilglizerola eta anandamida. Kannabinoide endogeno horiek CB1 zein CB2 kannabinoide-hartzaileei lotzen zaizkie zenbait funtzio fisiologiko erregulatzeko, batik bat oroimena, mina, gosea, umorea, immunitate-sistema, tenperatura eta ugalkortasuna. CB hartzaileak ehun ezberdinetan aurkitzen badira ere, CB1 hartzailea bereziki ugaria da NSZan (6) eta CB2 hartzailea, aldiz, immunitate-sisteman eta periferikoki (7). Aipatutako kannabinoide-hartzaileez gain, giza gorputzean barneko kannabinoideen sintesi- eta degradazioentzima espezifikoak ere aurkitu izan dira eta horiek guztiek barneko kannabinoide-sistema osatzen dute (8).

CB hartzaileak Gi/o proteina inhibitzaileei atxikita daude, hortaz hartzailea aktibatzean K+ ioien bidezko inhibizio neuronala gertatuko da. Kokapen neuronalari dagokionez, CB1 hartzaileak NSZko bukaera glutamatergiko eta GABAergikoetan bereziki ugariak dira. Kokapen horri esker kannabinoideek neurotransmisoreen askapena inhibi dezakete, neuromodulatzaile gisa jokatu eta horrela aktibitate neuronala erregulatu. Izan ere, kannabinoide batek neurona baten aferentzia kitzikatzailea (glutamatergikoa) inhibituko balu, neurona horren zeharkako estimulazioa eragingo luke. Aldiz, neurona batek jasotzen duen aferentzia inhibitzailea (GABAergikoa) blokeatzen bada, neurona horren zeharkako estimulazioa lor daiteke. Hainbat gune zentraletan frogatu da kannabinoideek neurotransmisio estimulatzailea eta inhibitzailea erregulatzen dutela. Adibidez, animalien NSZko nukleo noradrenergiko garrantzitsuenean, hots, locus coeruleus-ean (LC), CB1 hartzailearen aktibazioak sistema GABAergikoa eta glutamatergikoa erregulatzen ditu $(9,10)$ eta gune noradrenergiko horretara heltzen den aferentzia GABAergikorik garrantzitsuena inhibituz, bertako neuronen estimulazioa eragiten du (9). Garuneko gune serotonergikorik garrantzitsuenean ere, hau da, errafe dortsalean (ED), kannabinoideek interneurona GABAergikoak inhibitzen dituzte (11). Sistema horien erregulazioaren bidez posible da kannabinoideek minaren jatorrian dagoen seinaletransmisioa modulatzea. Izan ere, bai LC guneak eta bai EDak ere minaren erregulazio supraespinalean parte hartzen dute.

Estimulu periferiko mingarri batek eragindako seinalea neurotransmisore kitzikatzaileen bitartez hedatzen da bizkar-muinetik zehar. Horrela, seinalea nagusiki N-metil-D-aspartato (NMDA), azido aamino-3-hidroxi-5-metilo-4-isoxazolpropioniko (AMPA) eta tirosinkinasa motako hartzaileek bideratzen dute. Horretaz gain, aipagarria ere bada bizkar-adarrean askatutako neuropeptido eta neuromodulatzaile batzuen eragin kitzikatzailea. Horregatik, sinapsi osteko neuronek bizkar-muinean askatutako kannabinoideak, neuromodulatzaile gisa, behar-beharrezkoak dira periferiatik datozen bukaera sinaptikoak inhibitzeko eta horrekin seinalea gelditzeko (12). CB hartzaileak bizkar-muineko I., III. eta X. geruzetako interneuronetan ugariak badira ere (13), barneko sistema kannabinoidearen minaren modulazioan gune entzefalikoek berebiziko garrantzia dute. Izan ere, CB1 hartzaileen dentsitate altuenak entzefaloan daude (6). Horrela, CB hartzaileak akueduktuaren inguruko materia grisean aurkitu izan dira, zeina minaren beheranzko sistema inhibitzailearen kontrol-gunea baita. Gune horretako neuronek errafeko eta LCko neuronekin sinapsia egiten dute, nukleo horietako neuronen aktibitatea erregulatuz. LCak estimulu mekanikoak erregulatzen ditu, eta errafeak, aldiz, estimulu termikoak (14). Gainera, bi nukleo horietako sinapsietan ere aipatu den bezala CB hartzaileak aurkitu izan dira (8). Ondorioz, kannabinoideek minaren sorburu den seinalea erregula dezakete bizkar-muinean eta garuneko nukleo ezberdinetan dauden CB hartzaileen bitartez (15).

NSZko kannabinoide-analgesia nagusiki CB1 hartzaileak bideratzen badu ere, CB2 hartzailearen partaidetza ezin daiteke guztiz baztertu. Ebidentzia zientifikoen aldetik, ikerketa gehienek CB2 hartzaileek bideratutako analgesia hanturaren kontrako eraginaren bitartez azaltzen dute. Hau da, zelula immuneetan dauden CB2 hartzaileak aktibatuz hantura murriztu (16) eta hartzaile nozizeptiboen estimulazio kimikoa txikitzen dute. Hala ere, CB2 hartzaileak karraskarien zerebeloan eta burmuin-enborrean eta giza hipokanpoan aurkitu izanak eragin farmakologiko zentralaren hipotesia piztu du; betiere kontuan izanik hartzaile horien funtzionalitatea ikertzeko dagoela NSZan. Alde horretatik ere, tentu handiz interpretatu behar dira CB2 hartzaileei egotzi zaizkien eragin analgesikoak. Gainera, CB2 hartzailea erregulatzen duten farmakoen espezifikotasuna oro har eskasa 
da (17). Era berean, saguetan CB2 hartzailea deuseztatu arren, oinarrizko erantzun nozizeptiboa ez da nabarmenki aldatzen estimulu termikoen zein mekanikoen aurrean (18). Hau guztia kontuan hartuta, ikertu beharra dago CB2 hartzaileek bideratutako analgesiak bide neuronalei jarraitzen dien edota garuneko mikroglia eta astrozitoen bidezko zeharkako eraginik ote duen (17). Dena den, CB2 erregulatzaileen ikerketak itxaropentsua dirudi psikoaktibitatea ekidin dezaketelako eta CB1 erregulatzaileekin batera analgesia on bat lortzea posible litzatekeelako.

CB hartzaileen bidezko minaren erregulazioaz gain, badirudi kannabinoideek beste bide batzuk erabil ditzaketela minaren sorrera saihesteko. Ebidentzia gehien biltzen dutenen artean, transient receptor potential (TRP) ioi-erretenak aipa daitezke. Hartzaile horiek minaren bitartekari dira, zeluletan seinale elektrikoek sorraraziko duten katioien sarrera ahalbidetzen baitute. Ikerketen arabera, barneko kannabinoideek zein kanpokoek TRPak zuzenean aktibatu edo inhibitu ditzakete $(19,20)$. Gainera, McDowell-ek eta kideek 2013an argitaratutako ikerketaren arabera, CB1 hartzaileak bideratutako analgesiaren parte bat TRPV1 hartzailearen sentsibilizazioa saihestearen ondorioa izango litzateke (21). Hortaz, baliteke kasu batzuetan kannabinoideek eragindako analgesia hartzaile horien bidezkoa ere izatea.

\subsection{Landare-kannabinoideen eragin analgesikoa eta psikoaktibitatearen arazoa}

Aipatutako barneko kannabinoideez gain, badaude naturan horien ekintza-mekanismo bera duten molekulak ere. Kannabinoide exogenoek gune espinal, supraespinal zein periferikoki kokatzen diren CB hartzaileak aktibatuz efektu analgesikoa eragiten dute. Zehazki, kanpoko kannabinoideek analgesia zentrala eragin dezakete CB1 hartzaileak aktibatuz, aitzitik, analgesia periferikoa CB1 eta CB2 hartzaileen aldibereko aktibazioaren ondorioa da. Beraz, oro har, kannabinoide exogenoen eragin zentralak CB1 hartzaileak bideratzen ditu eta, CB2 hartzailea, aldiz, eragin periferikoez arduratzen da. Kanpoko kannabinoideen iturri naturalen artean, Cannabis generoko landareak garrantzitsuenak dira. Cannabis generoak 3 espezie biltzen ditu: sativa, indica eta rudelaris. Gainera, espezie bakoitzak ezaugarri propioak dituzten anduiak izan ditzake, adibidez, D9tetrahidrokannabinol (THC) eduki txikiko sativa espezieko andui haritsuak. Beraz, espezietik espeziera eta andui batetik bestera kannabinoideen eta beste osagai kimiko batzuen edukia asko alda daiteke. Orain arte, kannabisean identifikatutako 400 molekula kimikoen artean 113 landare-kannabinoide identifikatu izan dira. Horietako landare-kannabinoide asko beste kannabinoide baten forma oxidatuak baino ez dira, baina hala ere berezko propietateak dituzte (22).

Landare-kannabinoideak bi talde nagusitan bereiz daitezke: psikoaktiboak eta ez-psikoaktiboak. Psikoaktibitate deritzo pertzepzioa, jokaera edota konortea eraldatzeko propietateari eta ezaugarri hori terapeutikarako efektu desiragaitza da (adibidez, mina tratatzeko). Kanpoko kannabinoideen psikoaktibitatea garuneko CB1 hartzaileak aktibatzeko duten gaitasunarekin erlaziona daiteke. Gainera, kannabisarekiko menpekotasuna ere kannabinoideen psikoaktibitatearekin erlazionatu da. Aldi berean, CB1 hartzailea aktibatzeko gaitasunak ere eragin analgesikoak azal ditzake. Literatura zientifikoan urteetan zehar bildutako ebidentzien arabera, badirudi CB1 hartzailearen aktibazioa ezinbestekoa izango litzatekeela kannabinoide-analgesia eragiteko (23). Izan ere, THCak, kannabisaren kannabinoide psikoaktiborik ugarienak, saguetan min nozizeptiboa arintzen du CB1 hartzailea aktibatuz (24). Era berean, THCak edota kannabisaren aterakinek eragindako analgesia CB1 hartzaileak blokeatuz itzul daiteke (25). Beraz, THCak CB1 hartzaileak aktibatuz efektu analgesikoa eragiten du, baina aldi berean, esaterako, logura eta pertzepzioaren aldaketak eragiten ditu. Aldiz, kannabidiolak (CBD), kannabisaren kannabinoide ez-psikoaktiborik ugarienak, ez du zuzenean CB1 hartzailea aktibatzen eta, ondorioz, ez du pertzepzioan THCak duen eraginik (22). Horregatik, ikerkuntza kannabinoide ez-psikoaktiboetarantz bideratu da. Hala eta guztiz ere, CBDa bezalako kannabinoide ez-psikoaktiboen propietateek askotarikoak diruditen arren, ez zaie efektu analgesiko nabarmenik egotzi. Horrela, beste itu batzuk aktibatzeko gai badira ere (5-HT1A hartzailea esaterako), horien parte-hartzea ez dirudi nahikoa denik analgesia on bat eragiteko.

CB1 hartzaileak analgesia eragiteko duen garrantzia ikusita, azpimarragarriak izan daitezke CB1 hartzailearen agonista exogeno batek eragiten duen psikoaktibitatea saihesteko dauden estrategia posible batzuk. Esaterako, posible da CBDak CB1 hartzailea aktibatzeko duen zeharkako era aprobetxatzea. CBDak anandamidaren degradazio-entzima (FAAH) inhibi dezake in vitro $(19,20)$ eta 
gizakietan dagoeneko frogatu den moduan anandamidaren kontzentrazioa garunean handitu (26). Gaitasun horrek, esaterako, CBDaren psikosiaren kontrako efektuak azaltzen dituela ikusita (26), minerako ere antzekoa gerta daitekeela iradoki genezake (27). Hala ere, CBDaren gaitasun analgesikoaren inguruko ebidentziak eskasak izanik, ez dago argi zeharkako efektu hori analgesia eragiteko nahikoa den. Posible ere bada CB1 hartzailearen bidezko eragin zentralak saihesteko beste estrategia batzuk erabiltzea. Adibidez, Viñals-ek eta kideek CB1-5-HT2A dimeroen sorrera saihestuz THCaren bidezko analgesia eragin zuten saguetan, baina oroimen-arazorik eragin gabe (28). Beste ikertalde batek adenosinaren A2 hartzaileak deuseztatuz THCaren propietate analgesikoak mantendu zituzten, baina menpekotasunik eragin gabe (29). Bestalde, CB2 hartzaileari egotzi zaizkion propietate analgesikoak ikusita (17), ezin daiteke guztiz baztertu CB2 hartzailearekiko afinitate altuagoa duten landare-kannabinoide ez-psikoaktiboen (adibidez, kannabigerolaren) etorkizuneko erabilera. Amaitzeko, badirudi estrategia sinpleagoak ere erabilgarriak izan daitezkeela: kannabis terapeutikoaren dosiak txikitzea adibidez. Izan ere, gizakiekin eginiko ikerlan batean inhalatutako kannabisaren dosi txikiek ere eragin analgesiko azpimarragarriak aurkeztu zituzten min neuropatikorako, eragin psikoaktiboak urriak izanik (30).

\section{Kannabinoideen eta opiazeoen konbinazioa: sinergiaren oinarriak ikergai}

Aspalditik ezaguna da sinergia farmakologikoaren fenomenoa erabil daitekeela ez bakarrik propietate terapeutikoak indartzeko, baita segurtasuna hobetzeko ere. Sinergiari esker, bi farmakoren arteko konbinazioak farmakoen banakako eraginak hobetzen ditu eta horri esker farmakoen dosi txikiagoak erabil daitezke eta eragin desiragaitzak murriztu. Beraz, sinergiak segurtasuna eta eraginkortasuna hobetu ditzake. Azken urteotan, kannabinoideen eta opiazeoen arteko konbinazioaren eragin analgesiko sinergikoa ikergai dago. Sinergia horrek barneko sistema kannabinoideak eta sistema opioideak duten antzekotasunean du oinarri. Izan ere, bi sistemek transdukzio eta beheranzko transmisio analgesiko analogoak dituzte. Bai kannabinoideak eta bai hartzaile opioideak Gi/o proteinei atxikita daude, eta beraz beheranzko transdukzio-sistema bera erabiltzen dute (31). Kokapenaren aldetik, berriz, CB1 eta m opioide hartzaileak mina erregulatzen duten gune anatomiko berdinetan agertzen dira, hots, bizkar-adarretan, bizkar-muinean zein garuneko zenbait egituratan (31). Eragin analgesikoei dagokienez, morfinaren eta THCaren ahalmen analgesikoak berdintsuak dira, bide ez-periferikoetatik ematen direnean. Dena dela, aipatzekoa da, orobat, badaudela desberdintasunak opiazeoek eta kannabinoideek eragiten duten efektu analgesikoan. Adibidez, kannabinoide-analgesia indartsuagoa da ehun kaltetuetan ehun osasuntsuetan baino, CB hartzaileen presentzia hantura- kaltea dagoenean opiazeoena baino garrantzitsuagoa delako. Era berean, min neuropatikoaren sorreran parte har dezaketen Ab eta Ad zuntzetan CB hartzaileak ugariagoak dira opiazeo hartzaileak baino (32). Hori dela-eta, kannabinoideak opioideak baino eraginkorragoak izan daitezke min neuropatikoaren tratamendurako $(32,33)$. Hori guztia kontuan hartuta, eta desberdintasunak desberdintasun, kannabinoide- eta opioide-sistema endogenoak analogotzat har daitezke eta horrek sinergiaren agerpena errazten du.

Ildo horretatik, eta eragin analgesiko sinergikoari dagokionez, ebidentzia ugari argitaratu dira. Opiazeoak eta kannabinoideak batera emateak bakoitzak banaka duen eragin analgesikoa handitzen du (31,34). Esaterako, WIN55212 (CB1/CB2 hartzailearen agonista edo aktibatzailea) eta morfina (hartzaile opioideen agonista) aldi berean emateak efektu analgesiko sinergikoa eragin zuen nerbio ziatiko kaltetua (min neuropatikoa) zeukaten saguetan (35). Era berean, CP55,940 (CB1/CB2 hartzaileen agonista edo aktibatzailea) eta morfina batera emateak nozizepzioaren inhibizio sinergikoa eragin zuen xafla beroan zein isatsa aldentzearen proban (36). Gainera, kannabinoideen eta opiazeoen arteko sinergia ez da farmakoa ematen den bidearen menpekoa, hau da, farmakoak aho bidetik (37) zein topikoki (38) emanda mantendu egiten da. Oro har, topikoki emateak segurtasuna handitu ohi du. Bestetik, inhibizio gurutzatua ere ikusi izan da, hots, opiazeoen eta kannabinoideen antagonistek kannabinoide/opioide-analgesia blokeatu dezaketela $(37,39,40)$. Gainera, CB1 hartzailea blokeatzean opiazeoen eragin desiragaitzak (menpekotasun fisikoa) desagerraraz daitezke (41), eta, modu berean, $\mathrm{m}$ hartzailerik gabeko arratoietan THCaren abstinentzia-sintomak nabarmenki murrizten dira (42). Hala eta guztiz ere, oraindik ez da ezagutzen/ezezaguna da bi sistemen arteko elkargunea zein den; izan ere, analgesiaren mekanismo zelularrak erabilitako ereduaren guztiz menpekoak baitira. Adibidez, ikusi da accumbens nukleoko 
neuronetan, $m$ eta CB1 hartzaileek sinergikoki lan egiten dutela AMPz/PKA bide komuna erabiliz; horretarako badirudi beste hartzaileen partaidetza (adibidez, adenosinaren A2A hartzailea) ezinbestekoa litzatekeela. HEK-293 zeluletan, aldiz, sinergiaren oinarria CB1/m konplexuen eraketan datza (43). Ondorioz, sinergiaren existentzia bera frogatu bada ere, oinarri molekularrak ikertzeko daude.

\section{Kannabinoideak terapeutikan: minaren tratamendura eta beste erabilera batzuetara bideratutako ikerketa klinikoak}

Kannabisak efektu ugari ditu: batzuk terapeutikoki aprobetxa daitezke eta beste batzuk ez dira hain desiragarriak. Erabilera terapeutikoaren ikuspuntutik, kannabisak propietate analgesikoak, gorakoaren kontrakoak, neurobabesgarriak edo espasmoaren eta hanturaren kontrakoak ditu. Bestetik, kannabinoide psikoaktiboen proportzioaren arabera eragin desiragaitzak ere baditu. Izan ere, kannabisak menpekotasuna, gaixotasun psikiatriko batzuen okertzea, zorabioa, gaitasun psikomotorraren murrizketa edota oroimen-arazoak sorraraz ditzake (22). Kannabisaren efektu batzuk murriztea posible bada ere (adibidez, andui ezberdinak erabiliz), argi dago zaila dela aipatutako arazoak saihestea eta horrek arazo etikoak zein legalak dakartzala. Gainera, kannabisaren kannabinoide-edukia kontrolatzeko konplexua denez, gero eta ohikoagoak dira kannabisaren eratorriak eta kannabinoide isolatuen nahasketak. Hori dela-eta, Europan, esaterako, herrialde gehienek kanpoko kannabinoide isolaturen bat onartzen dute klinikan, baina askok kannabis terapeutikoa debekatzen dute. Dena dela, onartutako kannabinoide gutxi horiei emandako erabilerak ere oso mugatuak izaten dira.

Kannabis terapeutikoa alde batera utzita, mundu-mailan kannabinoideetan oinarritutako farmako batzuk garatu dira. Erabilienak THCa, THCaren eratorriak, CBDa, eta THCaren eta CBDaren arteko nahasketak dira. Landare-THCa, THC sintetikoa (Dronabinol) zein THCaren analogoa (Nabilona) kimioterapiak eragindako gorakoaren aurka merkaturatuta daude. CBDa (Epidiolex), aldiz, ikerketa klinikoan III. fasean dago epilepsia pediatrikoa tratatzeko. Azkenik, THCaren eta CBDaren arteko nahasketak oro har onartuta daude Europan, Estatu Batuetan eta Kanadan. Espainian, zehazki, Sativex-a 2010. urtean onartu zen esklerosi anizkoitzaren espasmoak tratatzeko. Medikamentu horrek CBDa eta THCa 1:1 proportzioan daramatza. Dirudienez, THCari CBDa gehitzen zaionean, THCaren efektu psikoaktiboak arintzen dira eta aldi berean CBDaren berezko efektuak aprobetxa daitezke. Ondorioz, Sativex-ak izan ditzakeen eragin desiragaitzak ez dira THC isolatuaren berdinak izango.

Minaren tratamenduaren aldetik, azken urteotan kannabinoideekin hainbat saiakuntza kliniko argitaratu dira. Saiakuntza kliniko horiek aztertuz, bi dira atera daitezkeen ondorio nagusiak: kannabinoide exogenoen eraginkortasuna handiagoa da min neuropatikorako; bestetik, badirudi min nozizeptiboak tratatzeko kannabinoideak ezegokiak direla $(44,45)$. Argitaratutako saiakuntza kliniko askok Sativex-a dute oinarri. Farmako hori min neuropatikoa eta min onkologikoa tratatzeko erabilgarria izan daitekeela ikusi da. Gainera, urteak merkaturatuta daramatzanez, medikamentu horren segurtasuna frogatuta dago eta horrek haren ikerkuntza errazten du. Horrela, Sativex-a plazeboa baino hobea izan zen jatorri desberdinetako min neuropatikoa arintzeko, hala nola min periferikoa (46), bizkarrezurreko ebakuntzaren ondorengoa (47), nerbio-plexuen kalteak eragindakoa (48), esklerosi anizkoitzarekin erlazionatutakoa (49) Min onkologikoari dagokionez, 2012an eta 2010ean argitaratutako saiakuntza -klinikoetan Nabiximols-ak (Sativex) eta horren analogo batek min onkologikoa arindu zuten opiazeoekiko tolerantzia garatu zuten gaixoetan $(53,54)$. Bere aldetik, kannabis terapeutikoak ere hainbat min mota tratatzeko ebidentziak biltzen ditu, baina azaldutako arazoak direla-eta martxan dauden saiakuntza klinikoak urriagoak dira. Ondorioz, badirudi gaur egungo terapeutikak kannabinoide psikoaktibo eta ez-psikoaktiboen nahasketa orekatuetara joko duela (1. taula).

Azkenik, literatura zientifikoan zenbait ebidentzia kliniko aurki daitezke aurretik aipatutako opiazeoen eta kannabinoideen arteko sinergiari buruz. Esaterako, kannabisa oxikodonarekin (?] hartzailearen agonista) batera emateak opioide-analgesia handitu zuen min kronikoa jasaten zuten gaixoekin egindako saiakuntza klinikoan (55). Era berean, THC sintetikoak opiazeoekin tratatutako 
gaixoen analgesia hobetu dezakeela ikusi izan da (56). Aldiz, indibiduo osasuntsuetan kannabinoideen eta opiazeoen arteko sinergiak soilik minaren osagai afektiboak hobetu zituen, hau da, minaren pertzepzio psikologikoa (57). Beraz, barneko kannabinoide-sistema eta opioidea aldi berean aktibatuz posible da eragin analgesiko indartsuagoa lortzea, baina farmakoen dosi txikiagoak erabilita segurtasuna hobetzea (58). Opiazeoen eta kannabinoideen arteko sinergia norabide bietan azaltzen bada ere, esan beharra dago kannabinoideen gaitasuna opiazeoen eragin analgesikoa emendatzeko ikertuago dagoela, bai animalietan baita gizakietan ere (59). Laburbilduz, sinergiaren fenomenoari esker analgesia indartsuagoa eta seguruagoa lor daiteke (60).

1. taula. Kannabinoideekin minaren tratamendurako egindako saiakuntza klinikoak.

\begin{tabular}{|c|c|c|c|c|c|}
\hline \multicolumn{2}{|c|}{ Gaixotasuna } & Farmakoa & Lagina & Emaitzak & Erref \\
\hline \multirow[t]{8}{*}{$\begin{array}{l}\text { Min } \\
\text { neuro- } \\
\text { patikoa }\end{array}$} & Kalte periferikoa & $\begin{array}{l}\text { Sativex } \\
\text { (CBD:THC) }\end{array}$ & $n=125$ & $\begin{array}{llr}\text { Sativex-ak } & \text { minaren } & \text { adierazle } \\
\text { guztiak hobetu } & \text { zituen } \\
\text { plazeboarekin konparatuz eta } \\
\text { tratamendua } 52 \text { astez luzatu } \\
\text { ondoren eragin analgesikoa } \\
\text { mantendu egin zen. }\end{array}$ & [46] \\
\hline & $\begin{array}{l}\text { Bizkarrezurreko } \\
\text { ebakuntza }\end{array}$ & $\begin{array}{l}\text { Sativex } \\
\text { (CBD:THC) }\end{array}$ & $n=116$ & $\begin{array}{l}\text { Sativex-a plazeboa baino hobea } \\
\text { izan zen mina arintzeko Brief Pain } \\
\text { Inventory(BPI) eskalaren arabera. }\end{array}$ & [47] \\
\hline & $\begin{array}{l}\text { Esklerosi } \\
\text { anizkoitza }\end{array}$ & $\begin{array}{l}\text { Sativex } \\
\text { (CBD:THC) }\end{array}$ & $\mathrm{n}=20$ & $\begin{array}{l}\text { Sativex-ak, hilabete batean zehar } \\
\text { emanda, gaixoen mina eta bizi- } \\
\text { kalitatea hobetu zituen } \\
\text { plazeboarekin alderatuz. }\end{array}$ & [49] \\
\hline & $\begin{array}{l}\text { Nerbio-plexuen } \\
\text { lesioa }\end{array}$ & $\begin{array}{l}\text { Sativex } \\
\text { (CBD:THC) }\end{array}$ & $\mathrm{n}=48$ & $\begin{array}{l}\text { Sativex-a plazeboa baino hobea } \\
\text { izan zen minarekin erlazionatutako } \\
\text { bizi-kalitatearen adierazleetan. } \\
\text { Adibidez, loaren interferentzia } \\
\text { murriztu zuen. }\end{array}$ & {$[48]$} \\
\hline & $\begin{array}{l}\text { Artritis } \\
\text { erreumatoidea }\end{array}$ & $\begin{array}{l}\text { Sativex } \\
\text { (CBD:THC) }\end{array}$ & $n=58$ & $\begin{array}{l}\text { Mina eta loa hobetu egin ziren } \\
\text { plazeboarekin alderatuz eta } \\
\text { jasotako eragin desiragaitzak txikiak } \\
\text { edo ertainak izan ziren. }\end{array}$ & [52] \\
\hline & $\begin{array}{l}\text { min lokal } \\
\text { konplexuaren } \\
\text { sindromea }\end{array}$ & $\begin{array}{l}\text { Kannabis } \quad \text { (\% } \\
1.29 \mathrm{THC})\end{array}$ & $\mathrm{n}=39$ & $\begin{array}{l}\text { Kannabisaren dosi txikiak ohiko } \\
\text { analgesikoak bezain eraginkorrak } \\
\text { izan ziren. Gainera, eragin } \\
\text { desiragaitzak urriakizan ziren. }\end{array}$ & [30] \\
\hline & $\begin{array}{l}\text { HIESAri lotutako } \\
\text { min } \\
\text { neuropatikoa }\end{array}$ & $\begin{array}{l}\text { Kannabis (\% 1- } \\
8 \mathrm{THC} \text { ) }\end{array}$ & $\mathrm{n}=28$ & $\begin{array}{l}\text { Gutxienez \% } 30 \text { eko hobekuntza } \\
\text { jasan zuten gaixoak ugariagoak } \\
\text { ziren kannabisaren taldean } \\
\text { plazeboaren taldean baino. Oro } \\
\text { har, gaixoek kannabisa ondo onartu } \\
\text { zuten. }\end{array}$ & [50] \\
\hline & & $\begin{array}{ll}\text { Kannabis } & \text { (\% } \\
3.56 \mathrm{THC}) & \end{array}$ & $\mathrm{n}=50$ & $\begin{array}{l}\text { Kannabisak artifizialki eragindako } \\
\text { hiperalgesia murriztu zuen. }\end{array}$ & [51] \\
\hline
\end{tabular}




\begin{tabular}{|c|c|c|c|c|c|}
\hline \multicolumn{2}{|c|}{ Gaixotasuna } & Farmakoa & Lagina & Emaitzak & Erref \\
\hline \multirow[t]{2}{*}{$\begin{array}{l}\text { Min } \\
\text { neuro- } \\
\text { patikoa } \\
\text { eta } \\
\text { nozize- } \\
\text { ptiboa }\end{array}$} & $\begin{array}{l}\text { Jatorri } \\
\text { desberdine- } \\
\text { takoa }\end{array}$ & $\begin{array}{l}\text { Oxikodonarekin } \\
\text { edo morfinarekin } \\
\text { tratatutako gaixoei } \\
\text { kannabisa (\% } 3.56 \\
\text { THC) eman zieten }\end{array}$ & $n=21$ & $\begin{array}{l}\text { Kannabisak opioideen eragin } \\
\text { analgesikoa hobetu zuen, baina } \\
\text { odoleko opioide } \\
\text { kontzentrazioak aldatu gabe. }\end{array}$ & {$[55]$} \\
\hline & $\begin{array}{l}\text { Jatorri } \\
\text { desberdinetak } \\
\text { oa }\end{array}$ & $\begin{array}{l}\text { Opioideak hartzen } \\
\text { zituzten gaixoek } \\
\text { eta tratatu } \\
\text { gabekoek } \\
\text { Dronabinola } \\
\text { (THCaren isomero } \\
\text { sintetikoa) hartu } \\
\text { zuten }\end{array}$ & $n=30$ & $\begin{array}{l}\text { Dronabinola plazeboa baino } \\
\text { eraginkorragoa izan zen mina } \\
\text { arintzeko. Gainera, } \\
\text { dronabinolak ere opioide- } \\
\text { analgesia hobetu zuen. }\end{array}$ & {$[56]$} \\
\hline \multirow[t]{2}{*}{$\begin{array}{l}\text { Min } \\
\text { onkologik } \\
\text { oa }\end{array}$} & $\begin{array}{l}\text { Prostata, } \\
\text { bular, birika } \\
\text { eta urdail- } \\
\text { hesteetako } \\
\text { minbiziak }\end{array}$ & $\begin{array}{l}\text { Nabiximols } \\
\text { (Sativex) }\end{array}$ & $\begin{array}{l}\mathrm{n}=360 \\
(263 \mathrm{k} \\
\text { buka- } \\
\text { tu } \\
\text { zuten) }\end{array}$ & $\begin{array}{l}\text { Tratamenduak eragindako } \\
\text { hobekuntza esanguratsua izan } \\
\text { zen plazeboarekin konparatuz } \\
\text { eguneroko minaren neurketan. }\end{array}$ & {$[53]$} \\
\hline & $\begin{array}{l}\text { Prostata, bular } \\
\text { eta biriketako } \\
\text { minbiziak }\end{array}$ & THC edo THC:CBD & $\mathrm{n}=177$ & $\begin{array}{l}\text { Opioideen tratamendu } \\
\text { klasikoekin tratatu ezin zitekeen } \\
\text { mina, THCarekin zein THC:CBD } \\
\text { nahasketarekin hobetu zen. } \\
\text { Bestetik, THC:CBD konbinazioak } \\
\text { analgesia indartsuagoa eragin } \\
\text { zuen THCak baino. }\end{array}$ & {$[54]$} \\
\hline
\end{tabular}

\section{Ondorioak eta azkeneko hausnarketa}

Mina eta bereziki min kronikoa arintzeko farmako berrien ikerkuntza da medikuntzaren erronkarik handiena. Egun existitzen diren analgesikoen eraginkortasun/segurtasun erlazioa ez da ona. Opiazeoen tratamendu kronikoak, adibidez, menpekotasuna sor dezake eta aldi berean tratamenduaren eraginkortasunaren galera (tolerantzia). Hori dela-eta, ematen du beharrezkoa izango dela bestelako mekanismoak dituzten analgesikoak ikertzea, eta horien artean kannabinoideak aukera egokia izan daitezke. Gorputzez kanpoko kannabinoideak landareetan daude, eta horien artean bereziki ugari dira Cannabis generoko landareak. Kannabisaren propietate analgesikoen inguruko ebidentziak ugariak diren arren, psikoaktibitateak haren ikerkuntza eta erabilera terapeutikoa mugatu izan ditu. Egia bada ere kannabisak menpekotasuna sor dezakeela, landareak 400 konposatu kimiko baino gehiago ditu eta soilik gutxi batzuek dituzte propietate psikoaktiboak. Beraz, THCa kannabisaren psikoaktibitatearen arduradun nagusia izanda, baliteke propietate analgesikoak dituen landare-kannabinoide bakarra ez izatea. Horretarako, ezinbestekoa da landare-kannabinoideak modu isolatuan ikertzea eta orduan bai, landare-kannabinoide ezberdinen nahasketak probatzea. Izan ere, Sativex-aren inguruko ikerketek iradokitzen duten moduan, posible dirudi CB hartzaileen bidezko efektu analgesikoa lortzea, baina aldi berean beste mekanismo batzuen bitartez gehiegizko aktibazioak dakartzan efektuak murriztea. Are gehiago, behin landare-kannabinoideak eta horien ekintza-mekanismoak ezagututa, posible izan liteke kannabinoide sintetiko seguruagoak eta eraginkorragoak diseinatzea. Hain zuzen ere, kanpoko kannabinoideen erabilerak barneko sistemaren ezaguera ahalbidetzen du eta ezagutza horren bidez farmako seguruagoak garatu daitezke. Gainera, barneko sistemen elkarrekintzak ere erabilgarriak izan daitezke, hala nola kannabinoide- eta opioide-sistemen arteko sinergia. Lehenago edo beranduago ikerkuntzak minaren erronkari irtenbide egokiagoa emango dio, eta baliteke irtenbide 
bat kannabinoideak izatea, baina horretarako kannabinoideetan oinarritutako terapeutikak eta ikerkuntzak ez lituzkete kontsumo ludikoaren oztopo etiko eta legal berdinak jasan behar.

\section{Erreferentzia bibliografikoak}

1. Melzack R, Wall PD. Pain mechanisms: a new theory. Science. 1965 Nov;150(3699):971-9.

2. Yong RJ, Nguyen M, Nelson E, Urman RD. Pain Medicine. An essential review. Springer International; 2017.

3. Santamarta MT, Ulibarri I, Pineda J. Inhibition of neuronal nitric oxide synthase attenuates the development of morphine tolerance in rats. Synapse. $2005 \mathrm{Jul} ; 57(1): 38-46$.

4. Santamarta MT, Llorente J, Mendiguren A, Pineda J. Involvement of neuronal nitric oxide synthase in desensitisation of $\mu$-opioid receptors in the rat locus coeruleus. J Psychopharmacol. 2014 Oct;28(10):903-14.

5. Pablos P, Mendiguren A, Pineda J. Contribution of nitric oxide-dependent guanylate cyclase and reactive oxygen species signaling pathways to desensitization of $\mu$-opioid receptors in the rat locus coeruleus. Neuropharmacology. 2015 Dec;99:422-31.

6. Rinaldi-Carmona $M$, Pialot $F$, Congy $C$, Redon $E$, Barth $F$, Bachy $A$, Brelière JC, Soubrié $P$, Le Fur $G$. Characterization and distribution of binding sites for (3H)-SR 141716A, a selective brain (CB1) cannabinoid receptor antagonist, in rodent brain. Life Sci. 1996 Mar;58(15):1239-47.

7. Munro S, Thomas KL, Abu-Shaar M. Molecular characterization of a peripheral receptor for cannabinoids. Nature. 1993 Sep;365(6441):61-5.

8. Kendall D, Alexande S. Behavioral Neurobiology of the Endocannabinoid System. Heidelberg: Springer-Verlag; 2009.

9. Muntoni AL, Pillolla G, Melis M, Perra S, Gessa GL, Pistis M. Cannabinoids modulate spontaneous neuronal activity and evoked inhibition of locus coeruleus noradrenergic neurons. Eur J Neurosci. 2006 May;23:2385-94.

10. Mendiguren A, Pineda J. CB1 cannabinoid receptors inhibit the glutamatergic component of $\mathrm{KCl}-$ evoked excitation of locus coeruleus neurons in rat brain slices. Neuropharmacology. 2007 Feb;52(2):617-25.

11. Mendiguren A, Pineda J. Effect of the CB1 receptor antagonists rimonabant and AM251 on the firing rate of dorsal raphe nucleus neurons in rat brain slices. Br J Pharmacol. 2009 Nov;158(6):1579-87.

12. Hohmann AG, Tsou K, Walker JM. Cannabinoid suppression of noxious heat-evoked activity in wide dynamic range neurons in the lumbar dorsal horn of the rat. J Neurophysiol. 1999 Feb;81(2):575-83.

13. Drew LJ, Harris J, Millns PJ, Kendall DA, Chapman V. Activation of spinal cannabinoid I receptors inhibits C-fibre driven hyperexcitable neuronal responses and increases (35S)GTP. GTgS binding in the dorsal horn of the spinal cord of non-inflamed and inflamed rats. Eur J Neurosci. 2000 Jul;12:2079-86.

14. Dogrul A, Seyrek M, Yalcin B, Ulugol A. Involvement of descending serotonergic and noradrenergic pathways in CB1 receptor-mediated antinociception. Prog Neuropsychopharmacol Biol Psychiatry. 2012 Jul;38(1):97-105.

15. Hama A, Sagen J. Activation of spinal and supraspinal cannabinoid-1 receptors lead to antinociception in a rat model of neuropathic spinal cord injury pain. Brain Res. 2011 Sep;1412:44-54.

16. Naidu PS, Kinsey SG, Guo TL, Cravatt BF, Lichtman AH. Regulation of inflammatory pain by inhibition of fatty acid amide hydrolase. J Pharmacol Exp Ther. 2010 Jul;334(1):182-90.

17. Atwood BK, Mackie K. CB2: a cannabinoid receptor with an identity crisis. Br J Pharmacol. 2010 Jun;160(3):467-479.

18. Nadal X, La Porta C, Andreea Bura S, Maldonado R. Involvement of the opioid and cannabinoid systems in pain control: New insights from knockout studies. Eur J Pharmacol. 2013 Sep;716(13):142-57.

19. De Petrocellis L, Schiano Moriello A, Imperatore R, Cristino L, Starowicz K, Di Marzo V. A reevaluation of 9-HODE activity at TRPV1 channels in comparison with anandamide: 
enantioselectivity and effects at other TRP channels and in sensory neurons. Br J Pharmacol. 2012 Dec;167(8):1643-51.

20. De Petrocellis L, Ligresti A, Moriello AS, Allara M, Bisogno T, Petrosino S, Stott CG, Di Marzo V. Effects of cannabinoids and cannabinoid-enriched Cannabis extracts on TRP channels and endocannabinoid metabolic enzymes. Br J Pharmacol. 2011 Aug;163(7):1479-94.

21. McDowell TS, Wang ZY, Singh R, Bjorling D. CB1 Cannabinoid Receptor Agonist Prevents NGFInduced Sensitization of TRPV1 in Sensory Neurons. Neurosci Lett. 2013 Sep;551:34-8.

22. Pertwee, RG. Handbook of Cannabis. Oxford: Oxford University Press; 2014.

23. Zimmer A, Zimmer AM, Hohmann AG, Herkenham M, Bonner TI. Increased mortality, hypoactivity, and hypoalgesia in cannabinoid CB1 receptor knockout mice. Proc Natl Acad Sci USA. 1999 May;96:5780-5.

24. Bagüés A, Martín MI, Sánchez-Robles EM. Involvement of central and peripheral cannabinoid receptors on antinociceptive effect of tetrahydrocannabinol in muscle pain. Eur J Pharmacol. 2014 Dec;745:69-75.

25. Varvel SA, Bridgen DT, Tao Q, Thomas BF, Martin BR, Lichtman AH. 9-Tetrahydrocannbinol Accounts for the Antinociceptive, Hypothermic, and Cataleptic Effects of Marijuana in Mice. J Pharmacol Exp Ther. 2005 Jul;314(1):329-37.

26. Leweke FM, Piomelli D, Pahlisch F, Muhl D, Gerth CW, Hoyer C, Klosterkötter J, Hellmich M, Koethe D. Cannabidiol enhances anandamide signaling and alleviates psychotic symptoms of schizophrenia. Transl Psychiatry. 2012 Mar;2:e94.

27. Kaczocha M, Rebecchi MJ, Ralph BP, Teng YH, Berger WT, Galbavy W, Elmes MW, Glaser ST, Wang L, Rizzo RC, Deutsch DG, Ojima I. Inhibition of fatty acid binding proteins elevates brain anandamide levels and produces analgesia. PLoS One. 2014 Apr;9(4):e94200.

28. Viñals X, Moreno E, Lanfumey L, Cordomí A, Pastor A, de La Torre R, Gasperini P, Navarro G, Howell LA, Pardo L, Lluís C, Canela El, McCormick PJ, Maldonado R, Robledo P. Cognitive impairment induced by delta-9-tetrahydrocannabinol occurs through heteromers between cannabinoid CB1 and serotonin 5-HT2A Receptors. PLoS Biol. 2015 Jul;13(7):e1002194.

29. Soria G, Castañé A, Berrendero F, Ledent C, Parmentier M, Maldonado R, Valverde O. Adenosine A2A receptors are involved in physical dependence and place conditioning induced by THC. Eur J Neurosci. 2004 Oct;20(8):2203-13.

30. Wilsey B, Marcotte T, Deutsch R, Gouaux B, Sakai S, Donaghe H. Low-dose vaporized cannabis significantly improves neuropathic pain. J Pain. 2013 Feb;14(2):136-48.

31. Viganò $D$, Rubino T, Parolaro D. Molecular and cellular basis of cannabinoid and opioid interactions. Pharmacol Biochem Behav. 2005 Jun;81(2):360-8.

32. Guía básica sobre los cannabinoides. Sociedad española de investigación con cannabinoides. Madrid: Universidad Complutense; 2002. 78-9 pp.

33. Fox A, Kesingland A, Gentry C, McNair K, Patel S, Urban L, James I. The role of central and peripheral cannabinoid 1 receptors in the antihyperalgesic activity of cannabinoids in a model of neuropathic pain. Pain. 2001 May;92:91-100.

34. Welch S, Eads M. Synergistic interactions of endogenous opioids and cannabinoid systems. Brain Res. 1999 Nov;848:183-90.

35. Kazantzis NP, Casey SL, Seow PW, Mitchell VA, Vaughan CW. Opioid and cannabinoid synergy in a mouse neuropathic pain model. Br J Pharmacol. 2016 Aug;173(16):2521-31.

36. Tham SM, Angus JA, Tudor EM, Wright CE. Synergistic and additive interactions of the cannabinoid agonist $\mathrm{CP} 55,940$ with mu opioid receptor and alpha2-adrenoceptor agonists in acute pain models in mice. Br J Pharmacol. 2005 Mar;144(6):875-84.

37. Cichewicz DL, Martin ZL, Smith FL, Welch SP. Enhancement mu opioid antinociception by oral delta9-tetrahydrocannabinol: dose-response analysis and receptor identification. J Pharmacol Exp Ther 1999 May;289(2):859-67.

38. Yesilyurt O, Dogrul A, Gul H, Seyrek M, Kusmez O, Ozkan Y, Yildiz O. Topical cannabinoid enhances topical morphine antinociception. Pain. 2003 Sep;105(1-2):303-8.

39. Welch SP. Blockade of cannabinoid-induced antinociception by norbinaltorphimine, but not N,Ndiallyl-tyrosine-Aib-phenylalanine-leucine, ICI 174,864 or naloxone in mice. J Pharmacol Exp Ther 1993 May; 265(2):633-40 
40. Reche I, Fuentes JA, Ruiz-Gayo M. Potentiation of delta 9-tetrahydrocannabinol-induced analgesia by morphine in mice: involvement of mu-and kappa-opioid receptors. Eur J Pharmacol 1996 Dec;318(1):11-6.

41. Mas-Nieto M, Pommier B, Tzavara ET, Caneparo A, Da Nascimento S, Le Fur G, Roques BP, Noble F. Reduction of opioid dependence by the $\mathrm{CB}(1)$ antagonist SR141716A in mice: evaluation of the interest in pharmacotherapy of opioid addiction. Br J Pharmacol 2001 Apr;132(8):1809- 16.

42. Lichtman AH, Sheikh SM, Loh HH, Martin BR. Opioid and cannabinoid modulation of precipitated withdrawal in delta-9-tetrahydrocannabinol and morphine-dependent mice. J Pharmacol Exp Ther 2001 Sept;298(3): 1007 - 14.

43. Rios C, Gomes I, Devi LA. m opioid and CB1 cannabinoidreceptor interactions: reciprocal inhibition of receptor signaling and neuritogenesis. Br J Pharmacol. 2006 Jun;148(4):387-95.

44. Stevens AJ, Higgins MD. A systematic review of the analgesic efficacy of cannabinoid medications in the management of acute pain. Acta Anaesthesiol Scand. 2017 Mar;61(3):268-280.

45. Thaler A, Gupta A, Cohen SP. Cannabinoids for pain management. Adv Psychosom Med. 2011 Apr;30:125-38.

46. Nurmikko TJ, Serpell MG, Hoggart B Toomey PJ, Morlion BJ, Haines D. Sativex successfully treats neuropathic pain characterised by allodynia: a randomised, double-blind, placebo-controlled clinical trial. Pain. 2007 Dec;133(1-3):210-20.

47. Berman J, Bosworth T, Guy G Stott C. Sativex Spinal Cord Injury Study Group. Sativex in the treatment of central neuropathic pain due to spinal cord injury: a randomised controlled study. Paper presented at: British Pain Society Annual Scientific Meeting. Glasgow; April 2007.

48. Berman JS, Symonds C, Birch R. Efficacy of two cannabis based medicinal extracts for relief of central neuropathic pain from brachial plexus avulsion: results of a randomised controlled trial. Pain. 2004 Dec;112(3):299-306.

49. Russo M, Naro A, Leo A, Sessa E, D'Aleo G, Bramanti P, Calabrò RS. Evaluating Sativex ${ }^{\circledR}$ in Neuropathic Pain Management: A Clinical and Neurophysiological Assessment in Multiple Sclerosis. Pain Med. 2016 Jun;17(6):1145-54.

50. Ellis R, Toperoff W, Vaida F, van den Brande G, Gonzales J, Gouaux B, Bentley H, Atkinson JH: Smoked medicinal cannabis for neuropathic pain in HIV: a randomized, crossover clinical trial. Neuropsychopharmacology 2009 Feb;34:672-680.

51. Abrams D, Jay C, Shade S, Vizoso H, Reda H, Press S, Kelly ME, Rowbotham MC, Petersen KL: Cannabis in painful HIV-associated sensory neuropathy. Neurology 2007 Feb;68:515-521.

52. Blake DR, Robson P, Ho M, Jubb RW, McCabe CS. Preliminary assessment of the efficacy, tolerability and safety of a cannabis-based medicine (Sativex) in the treatment of pain caused by rheumatoid arthritis. Rheumatology (Oxford). 2006 Jan;45(1):50-2.

53. Portenoy RK, Ganae-Motan ED, Allende S, Yanagihara R, Shaiova L, Weinstein S, McQuade R, Wright S, Fallon MT. Nabiximols for opioid-treated cancer patients with poorly-controlled chronic pain: a randomized, placebo-controlled, graded-dose trial. J Pain. 2012 May;13(5):438-49.

54. Johnson JR, Burnell-Nugent M, Lossignol D, Ganae-Motan ED, Potts R, Fallon MT. Multicenter, double-blind, randomized, placebo-controlled, parallel-group study of the efficacy, safety, and tolerability of THC:CBD extract and THC extract in patients with intractable cancer-related pain. J Pain Symptom Manage. 2010 Feb;39(2):167-79.

55. Abrams DI, Couey P, Shade SB, Kelly ME, Benowitz NL. Cannabinoid-opioid interaction in chronic pain. Clin Pharmacol Ther. 2011 Dec;90(6):844-51.

56. Narang S, Gibson D, Wasan AD, Ross EL, Michna E, Nedeljkovic SS, Jamison RN. Efficacy of dronabinol as an adjuvant treatment for chronic pain patients on opioid therapy. J Pain. 2008 Mar;9(3):254-64.

57. Roberts JD, Gennings C, Shih M. Synergistic affective analgesic interaction between delta-9tetrahydrocannabinol and morphine. Eur J Pharmacol. 2006 Jan;530(1-2):54-8.

58. Maguire DR, France CP. Impact of Efficacy at the [?-opioid receptor on antinociceptive effects of combinations of ?-opioid receptor agonists and cannabinoid receptor agonists. J Pharmacol Exp Ther. 2014 Nov;351(2):383-9.

59. Desroches J, Beaulieu P. Opioids and Cannabinoids Interactions: Involvement in Pain Management. Curr Drug Targets. 2010 Apr;11(4):462-73.

60. Welch SP. Interaction of the cannabinoid and opioid systems in the modulation of nociception. Int Rev Psychiatry. 2009 Apr;21(2):143-51. 